\title{
The impact of turnip mosaic virus on physiological and morphological parameters of kale plants
}

\author{
Turnip mosaic virus'un yaprak lahana bitkilerinin fizyolojik ve morfolojik parametrelerine \\ etkisi
}

\author{
Mehmet Ali ȘEVİK*1,a, Nuran CANSIZ ${ }^{1, b}$ \\ ${ }^{1}$ Ondokuz Mayıs Üniversitesi, Ziraat Fakültesi, Bitki Koruma Bölümü, 55139, Samsun
}

• Geliş tarihi / Received: 23.02.2021 • • Düzeltilerek geliş tarihi / Received in revised form: 17.05.2021 • Kabul tarihi / Accepted: 05.06 .2021

\begin{abstract}
Kale is one of the most important leafy vegetables. Turnip mosaic virus (TuMV) is a Potyvirus of the family Potyviridae that causes diseases in kale plants. This study was carried out to determine effect of TuMV on morphological and physiological characteristics of kale plants. Relationships between TuMV infection and some morphological/physiological parameters of kale were determined. According to the results obtained, in TuMV-infected kale plants have reduced plant $(6.0 \%)$ and leaf $(13.9 \%)$ length, leaf width $(25.9 \%)$, stalk length $(8.6 \%)$, root length $(55.5 \%)$, plant fresh $(37.8 \%)$ and, dry $(38.9 \%)$ weight, root fresh $(43.8 \%)$, dry $(41.1 \%)$ weight, leaf chlorophyll (12.4\%) and water $(0.57 \%)$ contents There were significant differences $(\mathrm{p}<0.05)$ between healthy and infected plants for the morphological and physiological parameters.
\end{abstract}

Keywords: Brassicaceae, Growth characteristics, Kale, Physiological traits, Virus

$\ddot{O} z$

Yaprak lahana en önemli yapră̆ yenen sebze türlerinden biridir. Potyviridae familyası Potyvirus cinsi içerisinde yer alan Turnip mosaic virus (TuMV), yaprak lahana bitkilerinde hastalıklara neden olmaktadır. TuMV'nin yaprak lahana bitkilerinin morfolojik ve fizyolojik özelliklerine etkisini belirlemek amacıyla bu çalışma yürütülmüştür. TuMV enfeksiyonu ile yaprak lahana bitkisinin bazı morfolojik ve fizyolojik parametreleri arasındaki ilişkiler belirlenmiştir. Çalışmada elde edilen sonuçlara göre, TuMV enfeksiyonu yaprak lahanaların; bitki (\%6.0) ve yaprak (\%13.9) boyunda, yaprak (\%25.9) genişliğinde, sap (\%8.6) ve kök (\%55.9) uzunluğunda, bitki yaş (\%37.8) ve kuru (\%38.9) ă̆ırlı̆̆ında, kök yaş (\%43.8) ve kuru (\%41.1) ă̆ırlı̆̆ında, yaprak klorofil (\%12.4) ve su (\%0.57) içeriğinde azalmalara neden olmuştur. TuMV'nin yaprak lahana bitkilerinin morfolojik ve fizyolojik parametrelere etkisi bakımından, sağlıkl ve enfekteli bitkiler arasında önemli farklılıklar $(p<0.05)$ bulunmuştur.

Anahtar kelimeler: Brassicaceae, Gelişim özellikleri, Yaprak lahana, Fizyolojik özellikler, Virüs

\footnotetext{
${ }^{* a}$ Mehmet Ali ŞEVİK; malis@omu.edu.tr, Tel: (0362) 3121919, orcid.org/0000-0002-8895-7944

${ }^{\mathrm{b}}$ orcid.org/0000-0003-3093-6275
} 


\section{Introduction}

Turkey is suitable for cole crops production in terms of climatic conditions. The Brassicaceae family takes the lead in terms of production in cool climate vegetable species in Turkey (Turkstat, 2018). Species of the Brassicaceae family provide important contributions to human nutrition which are grown on a wider area of the world. Eastern Mediterranean countries and Anatolia are considered to be the origin of this group (Fang et al., 2005).

Kale (Brassica oleracea var. acephala) has an important role among the leafy green vegetables in Turkey. Kale cultivation and consumption in Turkey is usually produced intensively in the Black Sea region. Kale cultivation is one of the important agricultural activities in Samsun province as the first rank in terms of production (Turkstat, 2018). There are many factors that influence the quality and quantity of crops in kale production. Several viral pathogens cause disease in species of the Brassicaceae family (Raybould et al., 1999; Latham et al., 2003).

Turnip mosaic virus (TuMV) is one of the most common viruses that can infect a large number of cultivated plant species, especially the Brassicaceae family (Wang et al., 2015). TuMV, Potyvirus genus, the Potyviridae family, has flexible rod-shaped particles with a length of 700$750 \mathrm{~nm}$. The virus can spread non-persistently with infested plant materials which was attacked by numerous aphid species (Nguyen et al., 2013).

TuMV has been detected by previous studies as the most common virus in Brassica crops (Sevik, 2016a; Sevik, 2019). TuMV was found to be the most common virus in surveyed kale fields in Ordu (Sevik, 2016b) and Samsun (Akcura and Sevik, 2016) provinces in Black Sea Region of Turkey. TuMV may lead to significant yield and quality losses every year in plant species of the Brassicaceae family (Rusholme et al., 2007; Jiang et al., 2010). Yet no published findings were reported about the effect of viruses on kale plants which are grown intensively especially in the Black Sea Region of Turkey.

In this study, we aimed to determine the impact of TuMV on morphological and physiological traits in kale plants. The experiments were conducted to investigate the effect of the virus on kale plants.

\section{Material and method}

\subsection{TuMV isolate}

TuMV-BA isolate was isolated from cabbage plants in Samsun province. The virus was inoculated to kale seedlings in a climatic chamber (16 hours light at $24{ }^{\circ} \mathrm{C}$ and 8 hours dark at $18{ }^{\circ} \mathrm{C}$ ) in virology laboratory, Department of Plant Protection, Faculty of Agriculture, Ondokuz Mayis University. TuMV inoculated fresh kale leaves were used as virus inoculum in the experiments. The fresh leaves of infected kale were used as source of virus inoculum in the experiments.

\subsection{Plant materials}

Kale seed samples constitute the research that was obtained from commercial companies in the region. Kale seeds were germinated in viols containing sterile commercial peat. The seedlings were then transferred to large pots in the experiments.

\subsection{Mechanical inoculation}

Phosphate buffer solution (PBS) (pH: 7.0) $0.01 \mathrm{M}$ was freshly prepared and used for mechanical inoculation (Nguyen et al., 2013). TuMV-infected fresh leaves were homogenized in a chilled sterile mortar containing phosphate buffer solution $(1 \mathrm{~g} / 5$ $\mathrm{ml}$ ), carborundum was added and applied to kale plants at its four-leaf stage. The experiment was set up as five replications with twenty plants per repetition. The inoculated plants were kept in the greenhouse and observed for eight weeks (Guo et al., 2005).

\subsection{ELISA test}

The double-antibody sandwich Enzyme-linked immunosorbent assay (DAS-ELISA) was performed to detect the presence of TuMV in inoculated kale plants. DAS-ELISA was performed in line with the procedure reported by the company (Bioreba) where the kit was supplied. The absorbance $\left(A_{405}\right)$ in each well of the ELISA plates was read at $405 \mathrm{~nm}$ using an ELISA microplate reader (Tecan Spectra II, Austria). Samples with a value three times higher than the absorbance values of the negative controls were evaluated as positive. 


\subsection{Morphological and physiological measurements}

In the current study, plant length $(\mathrm{cm})$, root length $(\mathrm{cm})$, leaf length $(\mathrm{cm})$, leaf width $(\mathrm{cm})$, stalk length $(\mathrm{cm})$, plant fresh weight $(\mathrm{g})$, plant dry weight $(\mathrm{g})$, root fresh weight $(\mathrm{g})$, root dry weight $(\mathrm{g})$, leaf chlorophyll and water content (\%) were measured in kale plants. The chlorophyll contents of the plants were determined with a Konica Minolta SPAD-502 Plus one day prior to harvest. The average chlorophyll content was recorded at three different points on the top three leaves of each plant (Xie et al., 2016). In a total, fifteen measurements were made for each sample and the mean value was calculated.

The plants were washed with the tap water after harvest and it was measured from the root crown to the tip of the leaf with a millimetric ruler. The plant root length was assessed with the same ruler. For leaf width measurement, six young leaves ripening outwards from the middle were sampled and the distance between the edge points was measured with a ruler. Similarly, the leaf length was measured until the leaf stalk with a ruler. The length of the stalk, from the leaf blade up to the point where it was connected to the stem, was also measured with a ruler.

The weight of biomass and roots of the plants (washed with tap water and excess water removed) were individually measured on a $0.001 \mathrm{~g}$ precision digital balance (Kern, EW 220). For dry weight measurement, the biomass and roots were dried for 72 hours at $70{ }^{\circ} \mathrm{C}$ in a drying oven and weighed again with a precision balance (Aksu et al., 2017). Leaf water content was calculated via biomass and dry mass values after drying of the leaf sample in the drying oven (Wang et al., 2011).

\subsection{Statistical analysis}

Statistical analyses were performed using an SPSS software package (Version 21.0, IBM Corp., NY). The plant-root length, leaf lengthwidth, stalk length, plant fresh-dry weight, root fresh-dry weight and chlorophyll content values were subjected to variance analysis with SPSS statistical package program.

\section{Results and discussion}

In this study, we evaluated the findings of the effects of TuMV, which is common in kale production areas, on the morphological and physiological characteristics of kale crops. Virus symptoms (light mosaic, mosaic, and local lesions) were observed in kale plants after fifteen days of TuMV inoculation. The symptoms in infected plants were consistent with the findings as observed in kale in previous studies. Symptoms were observed on leaves from all inoculated kale plants and TuMV was detected in inoculated plants by DAS-ELISA.

Values and statistical analyzes of some physiomorphological parameters (plant root length, leaf length width, stalk length, plant root fresh weight, plant root dry weight, chlorophyll water content) of kale crops were obtained at the end of the experiment as presented in Table 1 and summarized in Figure 1-3.

It has been determined that TuMV showed negative effect on morphological and physiological parameters in kale plants. When compared with healthy plants, TuMV infected plants reduced plant $(6.0 \%)$ and leaf $(13.9 \%)$ length, leaf $(25.9 \%)$ width, leaf stalk (8.6\%), root (55.5\%) length; plant fresh $(37.8 \%)$ and dry $(38.9 \%)$ weight, root fresh $(43.8 \%)$ and dry $(41.1 \%)$ weight and chlorophyll $(12.4 \%)$ content. There were significant differences $(p<0.05)$ found between the averages. It was observed that healthy and infected plants have a small difference $(0.57 \%)$ in leaf water content (Figure 1).

In the present study, it was determined that TuMV marked a negative effect on many morphological parameters in kale plants. Similar results have been obtained in studies on species of the Brassica genus (Liu et al., 1990). According to findings, TuMV usually leads to yield losses of around 30\% and reduces plant growth by up to $100 \%$ (Liu et al., 1996). According to a study conducted Kenya, the TuMV decreased kale plant and leaf length (Shattuck, 1992). Also, TuMV was found to show a significant decrease in leaf and root weight and marketable leaf counts in kale plants (Spence et al., 2007). Likewise, when compared to control plants at the end of the trial, it was determined that virusinfected plants caused decreases in fresh and dry mass. This result was consistent with the findings of the study with TuMV by Guo et al. (2005). 
Table 1. Variables used to determine the effect of TuMV on kale plants.

\begin{tabular}{|c|c|c|c|}
\hline Parameters & Infected & Control & Significance \\
\hline Plant length $(\mathrm{cm})$ & $28.2 \pm 3.97$ & $30.0 \pm 2.1$ & $*$ \\
\hline Leaf length $(\mathrm{cm})$ & $10.1 \pm 0.95$ & $11.8 \pm 0.17$ & $*$ \\
\hline Leaf width $(\mathrm{cm})$ & $6.8 \pm 0.49$ & $9.1 \pm 0.84$ & $* *$ \\
\hline Stalk length $(\mathrm{cm})$ & $8.2 \pm 2.70$ & $9.0 \pm 1.16$ & $*$ \\
\hline Root length (cm) & $2.0 \pm 0.97$ & $4.5 \pm 1.0$ & $* *$ \\
\hline Plant fresh weight (g) & $19.1 \pm 0.82$ & $30.7 \pm 0.78$ & $* *$ \\
\hline Plant dry weight (g) & $2.5 \pm 0.33$ & $4.1 \pm 0.78$ & $* *$ \\
\hline Root fresh weight (g) & $0.3 \pm 0.08$ & $0.6 \pm 0.39$ & $* *$ \\
\hline Root dry weight (g) & $0.1 \pm 0.03$ & $0.17 \pm 0.23$ & $* *$ \\
\hline Chlorophyll (\%) & $38.9 \pm 4.44$ & $44.4 \pm 3.6$ & $*$ \\
\hline Leaf water content $(\%)$ & $86.6 \pm 0.01$ & $87.1 \pm 0.01$ & - \\
\hline
\end{tabular}

*Significant at $5 \%$,

** Significant at $1 \%$. Average values in the row imply a statistically significant difference according to the Tukey test $(P<0.01)$. The average values in each case are followed by the value of the standard deviation.

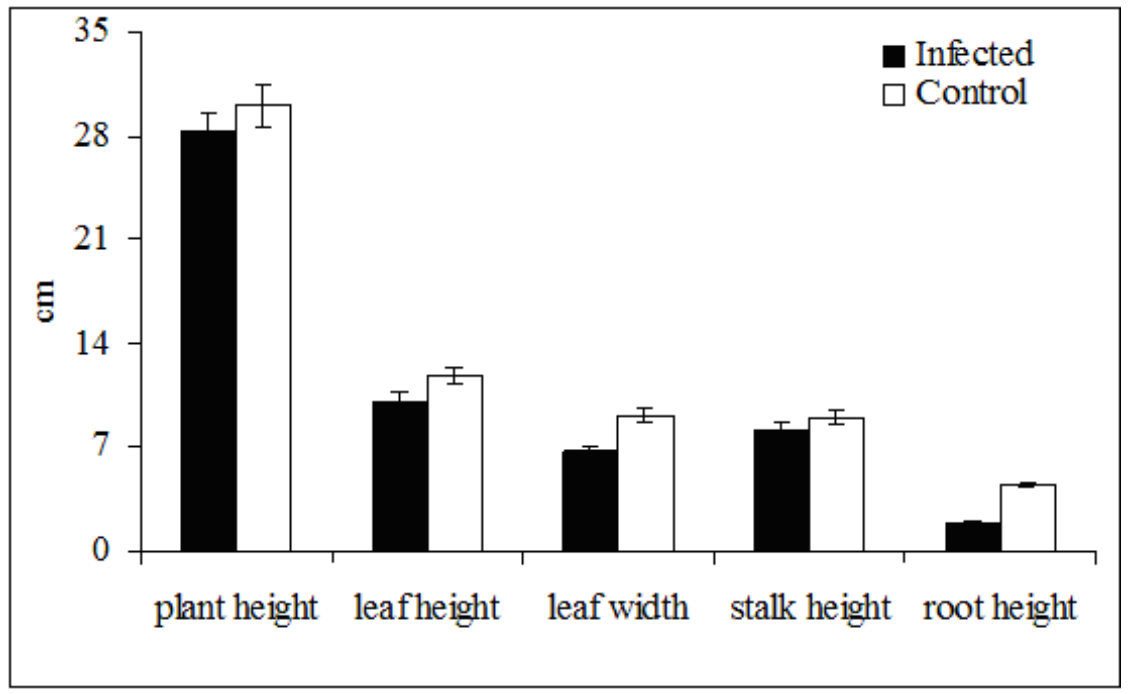

Figure 1. Length of plant, leaf, stalk, and root, leaf width at eight weeks in infected and control plants after TuMV infection.
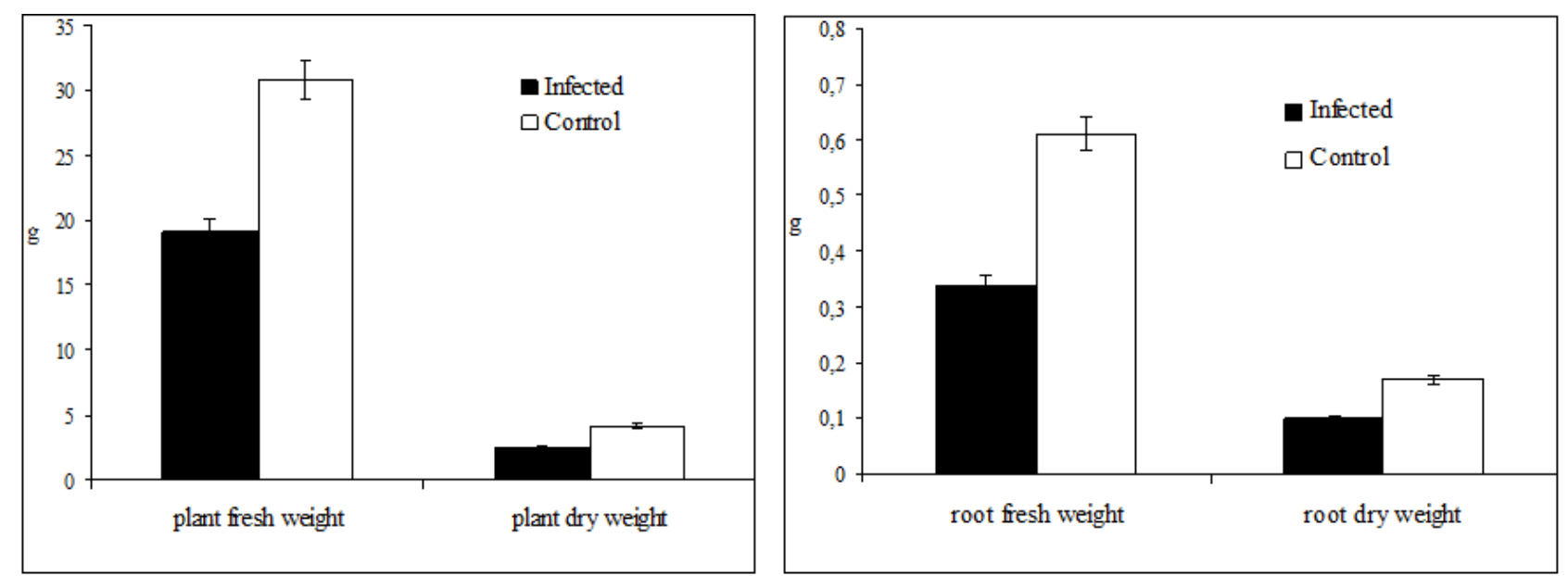

Figure 2. Fresh and dry weight of plants and roots at eight weeks after TuMV inoculation in infected and control plants. 


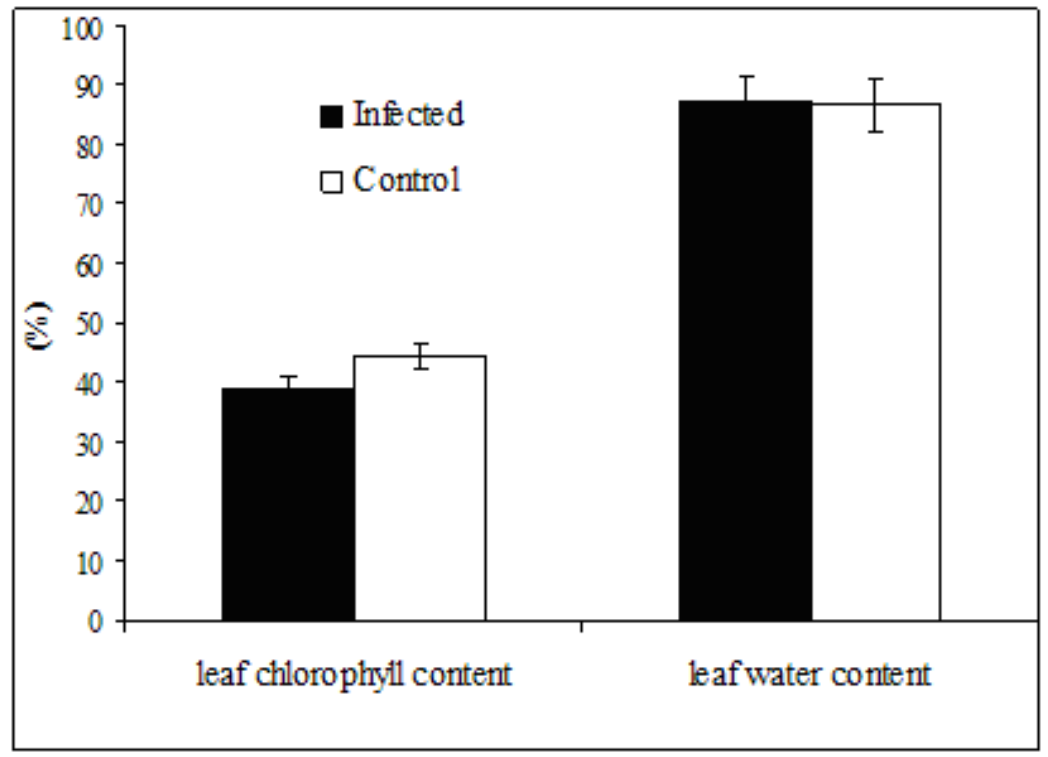

Figure 3. Leaf chlorophyll and water content in TuMV-infected and control plants at eight weeks after inoculation.

TuMV has been reported to cause $40 \%$ yield loss in Brassicas (Gorecka and Lehmann, 2001). Similarly, it has been reported by various researchers that the virus has lost yields as follows; $37-90 \%$ (Kolte, 2018) in China, 46\% (Jones et al., 2007) in Australia and 1.7-8.3\% (Tabarestani et al., 2010) in Iran.

Leaf chlorophyll content may be directly related to stress physiology and low chlorophyll content can directly affect photosynthesis in plants (Hooks et al., 2008). In this study, we found that the kale leaf chlorophyll content was decreased by $12.4 \%$. Similarly, leaf chlorophyll content of TuMVinfected mustard plants was found to be lower than the control plants (Guo et al., 2005).

\section{Conclusion}

In conclusion, TuMV is one of the most important viral pathogens that are common and can lead to serious loss of yields in Brassica crop. The effect of the TuMV infection on kale plant was examined in the current study. From this experiment, it was determined that the virus had a negative effect on yield and physio-morphological characteristics (plant root length, leaf length width, stalk length, plant root biomass, plant root dry mass, chlorophyll content) of kale plants. Statistical analyzes have shown a negative correlation between virus infection and some physio-morphological parameters. There were significant differences found between in infected and control plants.

\section{References}

Akcura, C. and Sevik, M. A. (2016). Determination of viruses in leaf cabbage production areas in Samsun province. Yuzuncu Yil University Journal of Agricultural Sciences, 26(2), 196-201.

Aksu, G., Temel, E. and Altay, H. (2017). Effects of potassium iodide foliar applications on iodine enrichment of rocket plant (Eruca vesicaria). Canakkale Onsekiz Mart University, Journal of Agriculture Faculty, 5(2), 97-104.

Fang, Z., Liu, Y., Lou, P. and Liu, G. (2005). Current trends in cabbage breeding. Journal of New Seeds, 6(2-3), 75-107. https://doi.org/10.1300/J153v06n02_05

Gorecka, K. and Lehmann, P. (2001). Infectious diseases of horseradish (Cochlearia armoracia L.) in Poland. Plant Breeding and Seed Science, 45(1), 55-64.

Guo, D. P., Guo, Y. P., Zhao, J. P., Liu, H., Peng, Y., Wang, Q. M. and Rao, G. Z. (2005). Photosynthetic rate and chlorophyll fluorescence in leaves of stem mustard (Brassica juncea var. tsatsai) after Turnip mosaic virus infection. Plant Science, $\quad$ 168(1), 57-63. https://doi.org/10.1016/j.plantsci.2004.07.019

Hooks, C. R. R., Wright, M. G., Kabasawa, D. S., Manandhar, R. and Almeida, R. P. P. (2008). Effect of Banana bunchy top virus infection on morphology and growth characteristics of banana. Annals of Applied Biology, 153(1), 1-9. https://doi.org/10.1111/j.1744-

7348.2008.00233.x 
Jiang, Y., Wang, J. H., Yang, H., Xu, M. Y., Yuan, S., Sun, W. and Lin, H. H. (2010). Identification and sequence analysis of Turnip mosaic virus infection on cruciferous crops in southwest of China. Journal of Plant Pathology, 92(1), 241244. https://dx.doi.org/10.4454/jpp.v92i1.37

Jones, R. A. C., Coutts, B. A. and Hawkes, J. (2007). Yield-limiting potential of Beet western yellows virus in Brassica napus. Australian Journal of Agricultural Research, 58, 788-801. https://doi.org/10.1071/AR06391

Kolte, S. J. (2018). Diseases of Annual Edible Oilseed Crops: Rapeseed-Mustard and Sesame Diseases. CRC press, USA.

Latham, L. J., Smith, L. J. and Jones, R. A. C. (2003). Incidence of three viruses in vegetable brassica plantings and associated wild radish weeds in south-west Australia. Australasian Plant Pathology, 32(3), 387-391. https://doi.org/10.1071/AP03031

Liu, X. P., Lu, W. C., Liu, Y. K. and Li, J. L. (1990). A study on TuMV strain differentiation of cruciferous vegetables from ten provinces in China. Chinese Science Bulletin, 35, 1734-1739.

Liu X. P., Lu, W. C., Liu, Y. K. and Wei, S. Q. (1996). Occurrence and strain differentiation of Turnip mosaic potyvirus and sources of resistance in Chinese cabbage in China. Acta Horticulturae, 407 , 431-440. https://doi.org/10.17660/ActaHortic.1996.407.5 5

Nguyen, H. D., Tomitaka, Y., Ho, S. Y. W., Duchene, S., Vetten, H. J., Lesemann, D. and Ohshima, K. (2013). Turnip mosaic potyvirus probably first spread to Eurasian Brassica crops from wild orchids about 1000 years ago. PLoS One, 8, 113.

https://doi.org/10.1371/journal.pone.0055336

Raybould, A. F., Maskell, L. C., Edwards, M. L., Cooper, J. I. and Gray, A. J. (1999). The prevalence and spatial distribution of viruses in natural populations of Brassica oleracea. New Phytologist, $\quad 141$ 265-275. https://doi.org/10.1046/j.1469-

8137.1999.00339.x

Rusholme, R. L., Higgins, E. E., Walsh, J. A. and Lydiate, D. J. (2007). Genetic control of broadspectrum resistance to Turnip mosaic virus in Brassica rapa (Chinese cabbage). Journal of General Virology, 88(11), 3177-3186. https://doi.org/10.1099/vir.0.83194-0

Sevik, M. A. (2016a). Viruses infecting brassica crops in the Black Sea Region of Turkey. Acta
Agriculturae Scandinavica, Section B-Soil \& Plant Science, 66(7), 553-557.

Sevik, M. A. (2016b). Turnip mosaic virus infecting kale plants in Ordu, Turkey. Phyton-International Journal of Experimental Botany, 85, 231-235. https://doi.org/10.1080/09064710.2016.1199731

Sevik, M. A. (2019). Viruses infecting cool season crops in the northern Turkey. Anais da Academia Brasileira de Ciencias, 91(3): e20180224. https://doi.org/10.1590/00013765201920180224

Shattuck, V. I. (1992). The biology, epidemiology and control of Turnip mosaic virus. J. Janick (Ed) Plant breeding reviews (pp. 199-238). New York, John Wiley and Sons.

Spence, N. J., Phiri, N. A., Hughes, S. L., Mwaniki, A., Simons, S., Oduor, G., Chacha, D., Kuria, A., Ndirangu, S., Kibata, G. N. and Marris, G. C. (2007). Economic impact of Turnip mosaic virus, Cauliflower mosaic virus and Beet mosaic virus in three Kenyan vegetables. Plant Pathology, 56, 317-323. https://doi.org/10.1111/j.13653059.2006.01498.x

Tabarestani, A. Z., Shamsbakhsh, M., \& Safaei, N. (2010). Distribution of three important aphid borne canola viruses in Golestan province. Iranian Journal of Plant Protection Science, 41(2), 251-259.

Turkstat. (2018). Turkish statistical institute, Production values of crop products. http://tuikapp.tuik.gov.tr/bitkiselapp/bitkisel.zul. Accessed 20 October 2018.

Wang, L, Hunt Jr. E. R., Qu, J. J., Hao, X. and Daughtry, C. S. (2011). Estimating dry matter content of fresh leaves from the residuals between leaf and water reflectance. Remote Sensing Letters, 2(2), 137-145.

https://doi.org/10.1080/01431161.2010.503973

Wang, Z., Jiang, D., Zhang, C., Tan, H., Li, Y., Lv, S. and Cui, X. (2015). Genome-wide identification of turnip mosaic virus-responsive microRNAs in non-heading Chinese cabbage by highthroughput sequencing. Gene, 571(2), 178-187. https://doi.org/10.1016/j.gene.2015.06.047

Xie, T. T., Su, P. X., An, L. Z., Shan, L. S., Zhou, Z. J., \& Chai, Z. P. (2016). Physiological characteristics of high yield under cluster planting: photosynthesis and canopy microclimate of cotton. Plant Production Science, 19(1), 165-172. https://doi.org/10.1080/1343943X.2015.112808 8 